\section{Waste issue threatens reactor}

\section{Munich}

Even a small nuclear reactor can stir up a large controversy in West Germany. This truism, which became even truer after Chernobyl, is being demonstrated once again in West Berlin, as a political dispute over waste disposal threatens licensing of the research reactor at the Hahn-Meitner Institute (HMI), the city's only Large Research Establishment.

An article in the magazine Spiegel on 23 April declared that spent fuel rods from six West German research reactors, including the one at HMI, consist of 93 per cent uranium-235 - "pure bomb material". Spiegel says that uranium from the fuel rods, which have in the past been returned to the United States after use, may wind up in US nuclear bombs.

HMI spokesman Thomas Robertson rejects SPD's arguments as "nonsense" for two reasons. He says that buying US fuel rods for the reactor and returning them when they are spent removes uranium-235 from the nuclear fuel cycle, rather than adding it, and that plutonium in the rods would be too strongly contaminated to serve as raw material for a bomb. Furthermore, he adds, the United States already has so much weapons material that it would be irrelevant whether these few fuel rods added to it.

Nevertheless, West Berlin Senator Barbara Riedmüller-Seel (Social Democrat, SPD) sent a letter to West German Research Minister Heinz Riesenhuber (Christian Democrat) asking the Research Ministry, as 90 per cent shareholder in HMI, to promise that the spent fuel rods were not being recycled into bombs.

Robertson doubts that Riesenhuber could give the assurance that SPD has asked for.

The letter from Riedmüller-Seel seems to represent a turnabout in the West Berlin SPD's grudging acceptance of the necessity of licensing the reactor. The HMI reactor was shut down three years ago for upgrading to a more powerful neutron source, but in the meantime there have been such grave problems with waste transport and disposal in the United States that HMI signed a new contract for waste disposal with the Dounreay facility in Britain.

Robertson admits that fuel from research reactors is not kept separate from bomb material at Dounreay, but he asserts that the Environment Ministry in Bonn, which is also responsible for reactor safety, has approved of the Dounreay waste disposal plan.

Squabbles over the licensing procedure have several times brought the fragile coalition between the SPD and the antinuclear Alternative List, the local branch of the Green Party, to the brink of collapse (see Nature 341, 479; 1989). But the SPD may be trying to have its cake and eat it too - trying to please its anti-nuclear supporters while at the same time declaring its support for the reactor. A spokeswoman for Riedmüller-Seel, Sigrid Kneist, says that the letter to Riesenhuber was not an attempt to delay the licensing, which SPD has promised by the end of May.

Kneist says that the West Berlin government realizes how high the stakes are: Siegfried Grossmann, the nominee for the vacant directorship of $\mathrm{HMI}$, has SOVIET SCIENCE

\section{US Academy describes anti-semitism}

\section{Washington}

AmID reports of rising anti-semitism in the Soviet Union, the US National Academy of Sciences recently urged the Soviet authorities to condemn anti-semitic attacks and persecution. The two-paragraph resolution, adopted at the 127 th annual meeting of the body, notes cases of "harassment or worse", and asks responsible authorities to "use all available means to prevent their further occurrence". Many Jewish scientists in the Soviet Union are concerned pogroms, according to former Soviet scientist Valery Soyfer, a molecular biologist at Ohio State University who has been monitoring reports of anti-semitism in the Soviet Union. He says one recent lecturer at a Soviet science centre, discussing the Jewish influence in the country, told his audience that machine nuts in the Soviet Union have six sides, rather than four, because of "Zionist propaganda". "Even inside academic institutions there are such battles", Soyfer says.

G. Christopher Anderson about the threat of persecution and even

\section{London}

BRITISH Nuclear Fuels plc (BNFL), shaken recently by the Gardner report's association between childhood leukaemia and paternal radiation exposure at the Sellafield nuclear reprocessing plant, has welcomed a $£ 225$ million contract to reprocess 450 tonnes of reactor fuel from Lingen, West Germany.

The contract is the first to be signed for reprocessing in the twenty-first century at BNFL's Thermal Oxide Reprocessing Plant (due to open at Sellafield some time in 1992).

With the future development of Britain's nuclear programme in abeyance until 1994 , overseas contracts are set to become said that he will take the job only if the licensing proceeds on schedule. The West Berlin Senate was planning to discuss the issue on 8 May.

Depending on Riesenhuber's response, the row may have dramatic consequences for other research reactors in West Germany at Jülich, Garching and elsewhere. The problem may resurface in an especially acute way in Garching, near Munich, where a project to build a new research reactor on the Technical University campus has been stalled for several years, in part because the Bavarian government feared a local backlash from opponents of nuclear energy.

\section{Steven Dickman}

\section{UK SPACE SCIENCE}

\section{Optimism, but little money \\ London}

ANNOUNCING approval from the Science and Engineering Research Council for a $£ 17$ million British involvement in two space projects, Professor Len Culhane from the Mullard Space Science Laboratory added that the climate for British space science was "substantially improved" after financial cuts in the $1980 \mathrm{~s}$. But this optimism, it seems, reflects a better state of mind, not increased funding. As Professor John Harries, head of space science at the Rutherford Appleton Laboratory, commented: "It's nice when someone stops hitting you".

The new money is for British teams to develop equipment for X-ray and ultraviolet astronomy missions. The X-ray multi-mirror mission, a 'cornerstone' of the European Space Agency's Horizon 2000 space programme, is due for launch in 1998.

Lyman-FUSE, a joint project with the United States and Canada to look at signals in the far and extreme ultraviolet, will fly in 1997.

Peter Aldhous

\title{
New order for BNFL
}

a more important part of BNFL's business.

Also at the end of last month, the Health and Safety Executive's Nuclear Installations Inspectorate approved plans for BNFL to operate its nuclear reactors at Chapelcross in Scotland and Calder Hall in Cumbria until 40 years old, subject to an estimated $£ 20$ million worth of safety improvements.

The reactors were designed with a 30 year lifespan, which they have now reached. Although reactors at both sites supply plutonium for Britain's nuclear weapons programme, BNFL say that the decision to continue operation is due to the reactors' commercial value as electricity generators.

Peter Aldhous 